\title{
Effect of Critical Risk Factors Causing Cost Deviation in Medium Sized Construction Projects
}

\author{
"Senthil Muthalvan Renuka and Chockkalingam Umarani
}

\begin{abstract}
Published online: 25 January 2019
To cite this article: Senthil Muthalvan Renuka and Chockkalingam Umarani (2018). Effect of critical risk factors causing cost deviation in medium sized construction projects. Journal of Construction in Developing Countries, 23(2): 63-85. https://doi.org/10.21315/jcdc2018.23.2.5
\end{abstract}

To link to this article: https://doi.org/10.21315/jcdc2018.23.2.5

\begin{abstract}
Risk is the outcome of an event which may be predicted on the basis of statistical probability. Construction projects have inherent risks associated with it. The main aim of this paper is to identify the critical risk factors and to propose a model to find the probability of cost deviation in medium sized construction projects. A total of 46 risk factors were shortlisted based on pilot study and experts' opinion. A questionnaire survey was conducted among 223 various construction professionals each representing one project i.e. from 223 different projects. Based on factor analysis, 46 risk factors which influence the cost deviation in construction projects were classified under nine key risk groups viz. project scope and evaluation risk, work environment risk, documentation and legal framework risk, construction and operational risk, resource productivity risk, knowledge sharing risk, site supervision risk, financial viability risk and lean construction risk. Logistic regression analysis was also carried out to develop a model to find the probability of cost deviation in construction projects. It is concluded that the risk groups such as project scope and evaluation risk, site supervision risk, knowledge sharing risk and lean construction risk are having higher influence in the cost deviation in medium sized construction projects. By setting the effective baseline of the project like estimation of original project cost and detailed project report, cost deviations in medium size construction projects can be eliminated. Detailed recommendations are also provided.
\end{abstract}

Keywords: Cost deviation, Risk management, Construction projects, India

\section{INTRODUCTION}

Construction sector is one of the key drivers for the growth of economy. Construction industry has unique features based on various factors such as time, process, budget and changing external factors including controllable and beyond human control. It is rare to find a construction project which is completely risk free (Taroun, 2014). A project is said to be a success when it is completed on time and within budget cost. Cost revisions and cost overruns are common across infrastructure projects. According to a recent report dated 30 November 2012 from Ministry of Statistics and Project Implementation (MoSPI) India, the ongoing central infrastructure projects are experiencing the cost overruns of $16.9 \%$ of their planned cost. On the other hand, the infrastructure investment in India is going to be USD 1 trillion during the 12th Five Year Plan (2014-2019) (Klynveld Peat Marwick Goerdeler [KPMG], 2013).

Division of Structural Engineering, Department of Civil Engineering, Anna University, Chennai, Tamil Nadu, INDIA

*Corresponding author: renuka@annauniv.edu 
Moreover, the small and medium sized projects are prone to more risks as they face more challenges than large projects (Smith and Bohn, 1999). Risks cannot be avoided or ignored. Risks are to be managed to overcome the impacts it has on projects such as cost, time, quality, brand image, etc. Risk management involves identification of factors causing risk, assessment, analysis of its impact on project and risk mitigation. However, risk management is often overlooked because risk management is tedious and costly strategy involving intensive information gathering and analysis (Mubarak, 2010). Construction professionals typically rely on their experience rather than using tools (Taroun, 2014). An extensive literature survey revealed that researchers have shown a remarkable contribution towards risk identification and assessment. Clearly, risk assessment ought to have a serious influence on contractors pricing strategy (Laryea and Hughes, 2011). Risk management implementation is relatively low in small and medium sized construction projects and this is due to lack of time and budget, low profit margin and uneconomical. But the results indicated a positive correlation between risk management implementation and improvement in project quality, cost, schedule and performance of projects (Hwang et al., 2014). Also, a formalised and standardised risk management process facilitates the cultivation of strong risk awareness and the flow of risk management information throughout the entire project life cycle (Hwang et al., 2014). Without a precise understanding of risks in reality, the contractors will not account the risks in pricing a bid. It would be hard for the contractors, to conceptualise analytical models for approaching risk response in the way that it normally happens in practice (Laryea and Hughes, 2011).

Considering Indian construction projects, a study has been carried out for analyzing the factors affecting delays with a sample size of 77 respondents (Doloi et al., 2012) and also it is found that not much of study has been carried out related to cost deviation in the Indian scenario with a large sample size. Hence it has become necessary to develop a simple statistical model that uses risk cost as a common scale and utilises professional experience to facilitate closing gap between theory and practice in medium sized construction projects. This paper expands the existing literature by identifying the critical risk factors and its impact on cost. It is also the need to develop a simple standardised model to assess the risks affecting the budget cost of the construction projects. An attempt is made to identify the critical risk factors causing cost deviation in Indian construction projects and to develop a model to find the probability of cost deviation in construction projects. This will be useful for the contractors during the pre-bidding stage, to provide some contingencies in bid pricing. The study area is limited to southern parts of India covering various types of construction projects like residential, commercial, infrastructural and industrial projects. Finally suitable recommendations are given for mitigate the risks during the life cycle of the project to make the project success.

\section{LITERATURE REVIEW}

Risk management in construction is still in its beginning nascent stage and the main cause lack of knowledge. Knowledge based risk management practice was required for best performance (Serpella et al., 2014). Cost deviations in a construction projects may develop in both directions (either positive or negative) depend on the prioritization of activities and management of the construction firm (Torp et al., 2016). Recently, more emphasis is given for research on cost deviation in Indian 
construction sectors. Various risk factors and its sub categories studied by various researchers were reviewed. The major risk categories and their sub factors for various sectors in developing countries as reported by earlier researchers are presented in Table 1. Risk categories and their sub factors are found to vary depending on the study location (country). The reasons for cost deviation are many. The factors like quality, safety, innovative construction technologies, and effective project management were also identified as critical risks, which will avoid cost deviation in construction project. Recently, number of systematic models have been proposed for use in the risk evaluation phase of the management process by past researches such as Dey (2002), Thomas et al. (2006), Zeng and Smith (2007), Abdelgawad and Fayek (2010), Eybpoosh et al. (2011) and Tamosaitiene et al. (2013). These researchers developed various risk assessment models using probability and impact (P\&I), Project evaluation and review technique (PERT), likelihood occurrence of risk (LR), Monte Carlo simulation (MCS), analytical hierarchy process (AHP), artificial neural networks (ANN), fuzzy logic and structural equation modeling (SEM). The assumptions underpinning analytical models of risk management may not be suitable in practice and what actually happens in practice is important (Laryea and Hughes, 2011). Challenges for the successful completion of project have to be identified and indexed at the beginning of the construction phase (Park et al., 2016). While assessing the project risk at the initial stage of the project, practitioners may not have sufficient data. Hence it is imperative to develop a simple regression model for each specific task. Moreover, simplicity is a key factor for encouraging professionals to use risk assessment tools in practice (Renuka et al., 2014). As a connection of such insightful thoughts and few attempts by various researches on risk management in Indian scenario, a model to find the probability of cost deviation in medium sized construction projects is proposed in this paper.

Table 1. Risk Factors from Literature

\begin{tabular}{llccc}
\hline Author & Risk Categories & Nos & $\begin{array}{c}\text { Sub } \\
\text { Factors }\end{array}$ & $\begin{array}{c}\text { Study } \\
\text { Location }\end{array}$ \\
\hline Chua and Li (2000) & $\begin{array}{l}\text { Nature of work, bidding requirements, } \\
\text { social and economic condition, firm } \\
\text { related factors }\end{array}$ & 4 & 51 & Singapore \\
$\begin{array}{l}\text { Shen, Wu and Ng } \\
\text { (2001) }\end{array}$ & $\begin{array}{l}\text { Financial, legal, management, } \\
\text { market, policy and political }\end{array}$ & 6 & 58 & China \\
$\begin{array}{l}\text { Dulaimi and Shan } \\
\text { (2002) }\end{array}$ & $\begin{array}{l}\text { Project characteristics, project } \\
\text { documentation, company related } \\
\text { issues, bidding situation, economic } \\
\text { situation }\end{array}$ & 5 & 40 & Singapore \\
Baloi and Price & $\begin{array}{l}\text { Estimator related risk, design } \\
\text { related risk, competition related risk, } \\
\text { fraudulent practices related risk, } \\
\text { construction related risk, economic } \\
\text { related risk and political related risk } \\
\text { Country level, market level, }\end{array}$ & 7 & 40 & Global risk \\
project level & 3 & 28 & Singapore \\
Wang, Dulaimi and \\
Aguria (2004)
\end{tabular}$\quad$\begin{tabular}{llll} 
\\
\hline
\end{tabular}


Table 1. (continued)

\begin{tabular}{|c|c|c|c|c|}
\hline Author & Risk Categories & Nos & $\begin{array}{l}\text { Sub } \\
\text { Factors }\end{array}$ & $\begin{array}{l}\text { Study } \\
\text { Location }\end{array}$ \\
\hline Bing et al. (2005) & $\begin{array}{l}\text { Macro-level, meso-level and } \\
\text { micro-level }\end{array}$ & 3 & 46 & $\begin{array}{l}\text { United } \\
\text { Kingdom }\end{array}$ \\
\hline $\begin{array}{l}\text { Zou, Zhang and } \\
\text { Wang (2007) }\end{array}$ & $\begin{array}{l}\text { Risks related to clients, risk related to } \\
\text { designers, risk related to contractors, } \\
\text { risk related to sub-contractors, } \\
\text { government agencies, external issues }\end{array}$ & 6 & 25 & China \\
\hline $\begin{array}{l}\text { Dikmen, Birgonul and } \\
\text { Han (2007) }\end{array}$ & $\begin{array}{l}\text { Technical risk, managerial risk, } \\
\text { resources risk, productivity risk, } \\
\text { client risk, sub-contractor risk }\end{array}$ & 6 & 12 & Turkey \\
\hline $\begin{array}{l}\text { Enshassi and Mosa } \\
\text { (2008) }\end{array}$ & $\begin{array}{l}\text { Physical, environmental, design, } \\
\text { logistic, financial, legal, constructional, } \\
\text { political and management }\end{array}$ & 9 & 44 & Palestine \\
\hline $\begin{array}{l}\text { Wang and Yuan } \\
\text { (2011) }\end{array}$ & $\begin{array}{l}\text { Knowledge and experience, } \\
\text { contractors character, personal } \\
\text { perception, economic environment }\end{array}$ & 4 & 16 & China \\
\hline $\begin{array}{l}\text { Ogunsanmi, Salako, } \\
\text { O.A. and Ajayi (2011) }\end{array}$ & $\begin{array}{l}\text { Cost related, time related and } \\
\text { quality related }\end{array}$ & 3 & 40 & Nigeria \\
\hline Toh et al. (2012) & $\begin{array}{l}\text { Project complexity, technological } \\
\text { requirements, project information, } \\
\text { project team requirements, contract } \\
\text { requirements, project duration, } \\
\text { market requirements }\end{array}$ & 7 & 79 & Malaysia \\
\hline $\begin{array}{l}\text { Goh, Rahman and } \\
\text { Samad (2013) }\end{array}$ & $\begin{array}{l}\text { Planning stage, design stage, } \\
\text { construction stage, handling over } \\
\text { stage }\end{array}$ & 4 & 25 & Malaysia \\
\hline $\begin{array}{l}\text { Baghdadi and Kishk } \\
(2015)\end{array}$ & $\begin{array}{l}\text { Internal, external and force } \\
\text { majeure risks }\end{array}$ & 3 & 54 & $\begin{array}{l}\text { Saudi } \\
\text { Arabia }\end{array}$ \\
\hline Park et al. (2016) & Risk factors in mega projects & 0 & 30 & Korea \\
\hline
\end{tabular}

\section{RESEARCH METHODOLOGY}

\section{Samples and Instruments}

A questionnaire survey approach was adopted to find the impact of various factors causing cost deviation in the Indian construction projects. The survey was conducted among various stakeholders represented by construction professionals spread across the southern part of India.

\section{Questionnaire Design}

Identification of critical factors for the study and the preparation of questionnaire was a crucial step for the success of the study (Doloi et al., 2012). In view of this, the major bottlenecks in Indian construction projects were identified by expert's 
interview. A structured questionnaire was developed with the collected primary data and also by incorporating the risk factors reported in the literature. The questionnaire consisted of two parts. Part 1 dealt with the general information about the respondents and the project and Part 2 dealt with the risk factors and its impact on the project cost. General information consisted of respondent's designation, respondent's experience, project location and the details of cost deviations in the particular project. Part 2 consisted of 61 identified risk factors. By purposive sampling technique, about 10 field experts in middle and top management level having more than 15 years industry experience in different projects were involved in the expert interview process. A pilot study was conducted with this prepared questionnaire to check the reliability of the questionnaire. Based on expert's opinion and by correlation analysis the risk factors were reduced to 46 risk factors and they are listed in Table 2. The factors having high correlation were eliminated and the final questionnaire was prepared comprising 46 risk factors. A five-point Likert scale (nil, low, moderate, high and very high) was adopted. Ranking of factors was carried out by calculating the overall mean value of each factor and thereby top five factors were identified. Followed by two statistical techniques namely factor analysis and binary logistic regression analysis were used in this study. Factor analysis was used to reduce the factors for investigating the effects while logistic regression was performed for deriving a probabilistic predictive model based on the best fit of variables for forecasting the probability of cost deviation in the construction projects (Doloi et al., 2012). The factor analysis was unable to depict the relationship between dependent variable and independent variable. Logistic regression analysis was considered as the most suitable method to derive the relationship between the variables. With this research methodology in mind a survey of individual interviews were conducted with Indian construction professionals to collect data by various methods. The respondents were requested to fill the hard copy of the questionnaire and collected in-person. Some responses were collected through email also. Respondents surveyed through email were requested to send responses by providing data in the required format (Doloi et al., 2012; Hwang et al., 2014).

Table 2. Identified Risk Factors with Descriptive Statistics

\begin{tabular}{|c|c|c|c|c|c|}
\hline $\begin{array}{l}\text { Factor } \\
\text { No. }\end{array}$ & Risk Factors & $\begin{array}{l}\text { Mean } \\
\text { Value }\end{array}$ & $\begin{array}{l}\text { Factor } \\
\text { No. }\end{array}$ & Risk Factors & $\begin{array}{l}\text { Mean } \\
\text { Value }\end{array}$ \\
\hline F1 & Funding arrangements & 2.62 & F24 & $\begin{array}{l}\text { Availability of materials, } \\
\text { sources and quality, } \\
\text { storage facilities }\end{array}$ & 2.70 \\
\hline F2 & $\begin{array}{l}\text { Standards and practices of } \\
\text { client }\end{array}$ & 2.48 & F25 & $\begin{array}{l}\text { Material wastages } \\
\text { exceeding the tolerance } \\
\text { limit }\end{array}$ & 2.52 \\
\hline F3 & $\begin{array}{l}\text { Contract type and } \\
\text { conditions and procedures } \\
\text { (payments, recoveries, } \\
\text { retention, pre-final and } \\
\text { final bill submission and } \\
\text { payments) }\end{array}$ & 2.48 & F26 & $\begin{array}{l}\text { Availability and } \\
\text { productivity of plant and } \\
\text { machinery (owned/hire), } \\
\text { working and maintenance } \\
\text { conditions, mobilisation }\end{array}$ & 3.04 \\
\hline
\end{tabular}


Table 2. (continued)

\begin{tabular}{|c|c|c|c|c|c|}
\hline $\begin{array}{l}\text { Factor } \\
\text { No. }\end{array}$ & Risk Factors & $\begin{array}{l}\text { Mean } \\
\text { Value }\end{array}$ & $\begin{array}{l}\text { Factor } \\
\text { No. }\end{array}$ & Risk Factors & $\begin{array}{l}\text { Mean } \\
\text { Value }\end{array}$ \\
\hline F4 & Unclarity of objectives & 2.57 & F27 & $\begin{array}{l}\text { Project quality plan } \\
\text { satisfies the requirement } \\
\text { of quality control and } \\
\text { quality assurance }\end{array}$ & 2.30 \\
\hline F5 & Client credibility & 2.19 & F28 & $\begin{array}{l}\text { Cost of rework and bad } \\
\text { workmanship }\end{array}$ & 3.18 \\
\hline F6 & Client specification & 3.16 & F29 & $\begin{array}{l}\text { Subcontractor and } \\
\text { vendors capability to } \\
\text { perform and delivery } \\
\text { methods }\end{array}$ & 2.51 \\
\hline F7 & Project schedule & 3.09 & $\mathrm{~F} 30$ & $\begin{array}{l}\text { Price escalation of } \\
\text { materials like steel, } \\
\text { cement, metals }\end{array}$ & 2.88 \\
\hline F8 & Design complexity & 2.96 & F31 & $\begin{array}{l}\text { Commissioning } \\
\text { requirement/handing over }\end{array}$ & 3.30 \\
\hline F9 & $\begin{array}{l}\text { Engineering inputs from } \\
\text { clients (soil investigation } \\
\text { report, no. of bores, earth } \\
\text { strata, etc.) }\end{array}$ & 2.44 & F32 & $\begin{array}{l}\text { Contract management } \\
\text { issues (claim preparation, } \\
\text { timely submission, } \\
\text { documentation) }\end{array}$ & 2.49 \\
\hline F10 & $\begin{array}{l}\text { Timely preparation and } \\
\text { delivery of drawing by } \\
\text { design team. }\end{array}$ & 2.51 & F33 & $\begin{array}{l}\text { Ambiguity of work } \\
\text { legislations }\end{array}$ & 2.39 \\
\hline F11 & $\begin{array}{l}\text { Availability of professional } \\
\text { competency and } \\
\text { experience }\end{array}$ & 2.58 & F34 & $\begin{array}{l}\text { Rules and regulations of } \\
\text { the government }\end{array}$ & 2.23 \\
\hline F12 & Location of site & 2.99 & F35 & $\begin{array}{l}\text { Visa formalities and } \\
\text { immigration rules }\end{array}$ & 2.04 \\
\hline F13 & Soil conditions & 2.71 & F36 & $\begin{array}{l}\text { Taxation laws by the } \\
\text { government (sales tax, } \\
\text { service tax, value added } \\
\text { tax [VAT], entry tax) }\end{array}$ & 2.06 \\
\hline F14 & $\begin{array}{l}\text { Site clearance/availability } \\
\text { of land }\end{array}$ & 3.21 & F37 & $\begin{array}{l}\text { Any conflicts with } \\
\text { government }\end{array}$ & 2.02 \\
\hline F15 & $\begin{array}{l}\text { Availability of power supply } \\
\text { at site, transport, approach } \\
\text { to site, proximity to train, } \\
\text { airport, port, telecom, } \\
\text { water and terrain }\end{array}$ & 2.68 & F38 & $\begin{array}{l}\text { Political stability for } \\
\text { clearance of the project }\end{array}$ & 2.36 \\
\hline F16 & $\begin{array}{l}\text { Difficulty in obtaining } \\
\text { permits, project approvals } \\
\text { from local bodies, } \\
\text { electricity board, water, } \\
\text { etc. }\end{array}$ & 2.75 & F39 & $\begin{array}{l}\text { Support or protest from } \\
\text { the local bodies for the } \\
\text { project }\end{array}$ & 2.09 \\
\hline
\end{tabular}


Table 2. (continued)

\begin{tabular}{|c|c|c|c|c|c|}
\hline $\begin{array}{l}\text { Factor } \\
\text { No. }\end{array}$ & Risk Factors & $\begin{array}{l}\text { Mean } \\
\text { Value }\end{array}$ & $\begin{array}{l}\text { Factor } \\
\text { No. }\end{array}$ & Risk Factors & $\begin{array}{l}\text { Mean } \\
\text { Value }\end{array}$ \\
\hline F17 & $\begin{array}{l}\text { Climate and weather } \\
\text { conditions which may } \\
\text { affect the progress of work/ } \\
\text { working hours }\end{array}$ & 2.34 & $\mathrm{~F} 40$ & $\begin{array}{l}\text { Interest, working capital } \\
\text { requirement, banking } \\
\text { requirements }\end{array}$ & 2.56 \\
\hline F18 & $\begin{array}{l}\text { Any extremist activities } \\
\text { (naxalaties, moist, mafia } \\
\text { groups, local dadas) }\end{array}$ & 2.31 & F41 & Cash flows in the project & 2.87 \\
\hline F19 & $\begin{array}{l}\text { Construction methods/ } \\
\text { quality/safety requirements } \\
\text { for workers }\end{array}$ & 2.69 & F42 & $\begin{array}{l}\text { Fluctuation in currency } \\
\text { rate }\end{array}$ & 2.38 \\
\hline F20 & Frontline supervisory force & 2.59 & F43 & $\begin{array}{l}\text { Misinterpretation and } \\
\text { misunderstanding of } \\
\text { bidding clauses and } \\
\text { documents }\end{array}$ & 1.75 \\
\hline F21 & $\begin{array}{l}\text { Support for import } \\
\text { formalities }\end{array}$ & 2.30 & F44 & $\begin{array}{l}\text { Termination of contract } \\
\text { and dispute resolution } \\
\text { (contract clauses to be } \\
\text { verified) }\end{array}$ & 2.21 \\
\hline F22 & $\begin{array}{l}\text { Availability of skilled and } \\
\text { competent labours (no. of } \\
\text { labours, wage escalation, } \\
\text { locally available labours) }\end{array}$ & 2.90 & F45 & Guarantees and bonds & 1.96 \\
\hline F23 & $\begin{array}{l}\text { Productivity of local } \\
\text { employees and ration of } \\
\text { local employment }\end{array}$ & 2.74 & F46 & $\begin{array}{l}\text { Vagueness of contract } \\
\text { laws and conditions }\end{array}$ & 2.12 \\
\hline
\end{tabular}

\section{Characteristics of Respondents}

Respondents were selected from a wide range of professionals engaged in the Indian Construction sector such as site engineers, project managers and planning managers. All the respondents identified had experience in large construction projects. The questionnaire was distributed by simple random sampling technique to around 500 various professionals working in construction projects spread across southern part of India. The respondents were asked to rate the factors and its impact on the project cost. Out of 500 distributed questionnaires 223 responses were received and the collected samples represented 223 different project details.

When the respondents' profile is considered, the highest contribution was from planning managers (43\%), followed by project managers (31\%) (Figure 1). The responses from the professionals with more than five years' experience were $75 \%$ which proves the good quality of responses (Figure 2). 


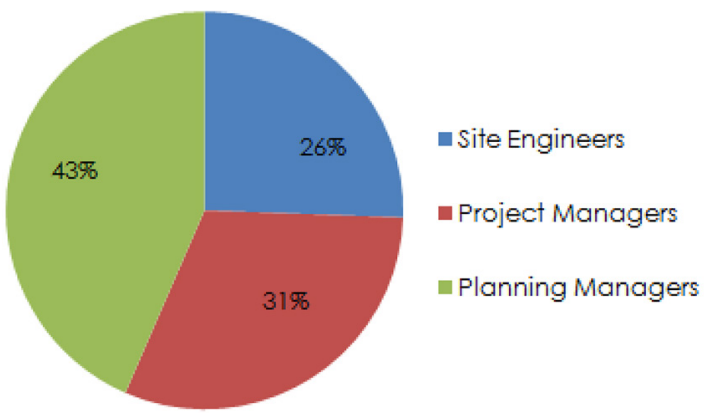

Figure 1. Respondents' Designation

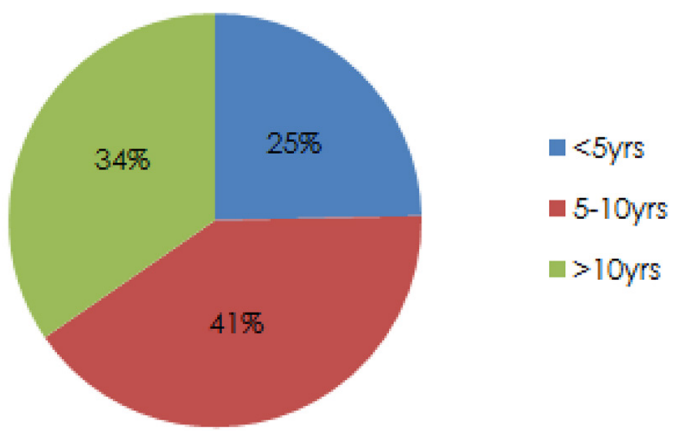

Figure 2. Respondents' Experience

\section{Characteristics of Projects}

The project details were obtained by covering major cities in southern part of India and they were categorised under four heads such as residential, commercial, industrial and infrastructural projects (Figure 3). It is found that the samples collected are a well proportionate mix having all types of projects, proving the reliability in the outcome of the research.

In order to derive the best possible outcome of the survey, the questionnaire and research objectives were explained to the professionals during data collection.

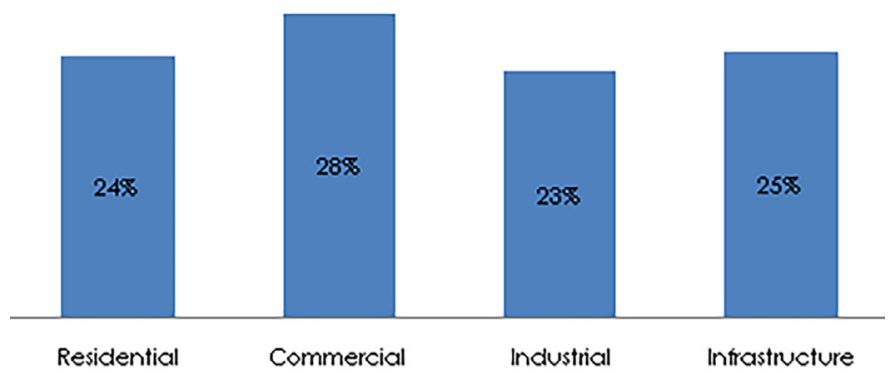

Figure 3. Different Types of Projects Involved in the Survey 
The project budget cost is between USD0.8 million and USD2.4 million as this study is limited to medium sized construction projects. The duration of the projects varied from 12 months and 48 months.

Ranking of factors: The factors are ranked based on the mean value and listed in Table 2. The top five factors with high mean value are commissioning requirement/handing over (F31) (3.30), site clearance/availability of land (F14) (3.21), cost of rework and bad workmanship (F28) (3.18), client specifications (F6) (3.15) and project schedule (F7) (3.09) whereas the lowest mean value factor is misinterpretation and misunderstanding of bidding clauses and documents (F43) (1.75).

\section{ANALYSIS, RESULTS AND DISCUSSIONS}

\section{Data Validation Using Reliability Analysis}

Outcome of the survey has direct relationship with the quality of responses. Hence reliability analysis is required to construct the predictive model for cost deviation. Cronbach's alpha test was performed on the entire collected data (Zinbarg et al., 2005). The value of Cronbach's alpha could be anywhere between 0 and 1 , whereas a higher value denotes the greater internal consistency and vice versa. From the analysis, the Cronbach's alpha value obtained was 0.974 which indicates higher reliability of the collected data and thereby factor analysis and binary logistic analysis were subsequently carried out.

\section{Data Reduction Using Factor Analysis}

Factor analysis is a statistical technique used to identify a relatively small number of uncorrelated factors that can be used to represent the relationship among sets of many interrelated variables. The same test was applied to the 46 questions posed to the respondents to find the cost implication of the different risks. In order to evaluate the adequacy of the survey data for factor analysis, Kaiser-Meyer-Olkin (KMO) test and Bartletts test of sphericity (Doloi et al., 2012) were carried out. In this research, KMO value was found to be 0.741 which was closer to 1. The Bartlett's test of sphericity showed that the approximate chi-square value was 9606.664 and the associated significance level was 0.000 , suggesting that the sample correlation matrix is not an identity matrix. Therefore it was deemed to be good for further study. To ensure the reliability of each factor, the Cronbach alpha value was used to test the internal consistency among the factors included in each group and it is indicated in the Table 3. Nunnally (1978) has recommended that a minimum of 0.7 is sufficient. Varimax rotation was applied to make it possible to discriminate between groups and ensure that the loadings of the variables are highest on one group and very less on others. Theoretically there can be 46 groups if there are 46 variables in the analysis. The eigenvalues associated with a variable indicates the substantive importance of that group. Therefore it becomes logical to retain only those groups which have higher eigenvalues. It was found that the eigenvalues of the groups were less than 1 after the ninth group. Hence, only nine groups were retained for the analysis and it is shown in scree plot Figure 4. The extraction and rotation of the factors were used to generate a small number of groups and to obtain a clear picture of what these factors represent. 


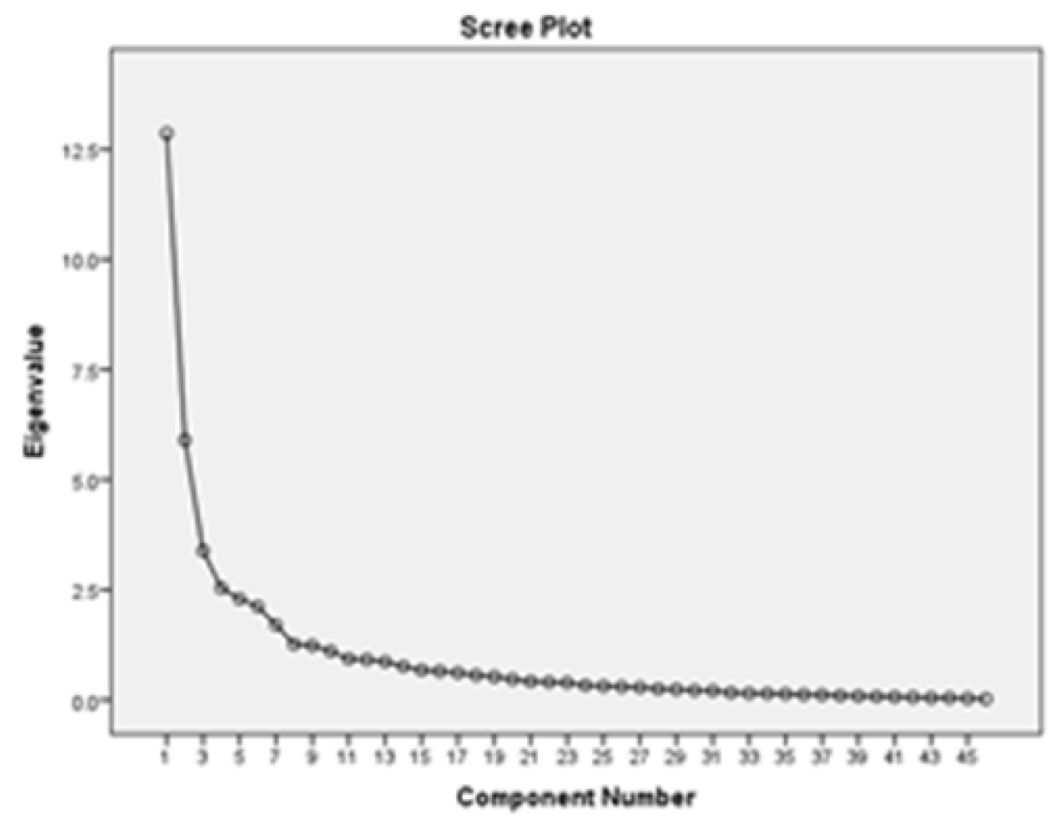

Figure 4. Scree Plot

Principal components analysis was used to identify the underlying factors. To determine how many groups were required to represent the set of data, the total percentage of variance explained by each group was examined (Hair et al., 2012). Principal factor extraction with a varimax rotation was carried out through the SPSS 20.0 factor analysis programme on 46 factors of risk management process from a sample of 223 responses. The details of factor loadings for each of the 46 factors and the total variance explained by each group are presented in Table 3. Principal component method was used in the analysis for extraction. Extraction of each group was carried out and the results depicted that all the variables were having communalities greater than 0.5. The total variance of each group and the cumulative variance were obtained. The groups having Eigen value greater than 1 were taken for the analysis. From this, nine groups were extracted, called underlying factors. Initially the total variance was explained for all the 46 factors and the nine underlying groups were extracted with the cumulative variance of $71.96 \%$. The summary of the results of the factor analysis is shown in Table 3 . The detailed discussion about the extracted groups is presented below.

\section{Extracted Groups}

\section{Group 1: Project scope and evaluation risk}

Group 1 accounts for $12.94 \%$ of total variance of the linear component and it consists of eight factors as shown in Table 3. Variance depends on following factors such as funding arrangements (F1), standard and practices of client (F2), contract type, conditions and procedures (F3), unclarity of objective (F4), client credibility (F5), 
availability of professional competency and experience (F11), subcontractor and vendor's capability to perform and delivery methods (F29), vagueness of contract laws and conditions (F46).

During evaluation and feasibility study of the project itself, the stakeholders should have clear understanding of the objective of the project, contract type, conditions, etc. which is crucial for successful completion of the project within budget. Contract managerial related issues can be easily overcome by employing experienced persons. Since the above mentioned eight factors are related to improper project evaluation, the Group 1 is named as "Project Scope and Evaluation Risk". It is suggested that for risk reduction, the contactors should assess the creditability of the client in addition to the above seven factors (viz., F1, F2, F3, F4, F5, F1 1, F29 and F46) before taking up any new project.

\section{Group 2: Work environment risk}

Group 2 accounts for $11.66 \%$ of total variance of the linear component and also has eight factors as shown in Table 3 . The factors under the work environment risk group includes engineering inputs from clients (F9), timely preparation and delivery of drawings by design team (F10), soil conditions (F13), any extremist activities (naxalaties, maoist, mafiagroups, local dadas) (F18), frontline supervisory force (F20), support for import formalities (F21), productivity of local employees and ration of local employment (F23), ambiguity of work legislations (F33).

Middle management and lower management supervision, involvement and commitment towards the project goal are the important driving force. Group 2 comprises managerial factors and team involvement that will identify problems in technical work, external issues and in motivating the team members and workers. Getting engineering inputs for the further continuation of work can be done by proper coordination of the supervisors. Safe work environment and good supervision will in turn increase the overall performance of a project.

\section{Group 3: Documentation and legal framework risk}

Group 3 accounts for $11.09 \%$ of total variance of the linear component and consists of eight factors as shown in Table 3. Group 3 consists of factors related to documentation and legal framework of the project. Sub factors of this group are Rules and regulations of the government (F34), visa formalities and immigration rules (F35), taxation laws by the government (F36), any conflicts with government (F37), political influence which may delay the award of the job (F38), misinterpretation and misunderstanding of bidding clauses and documents (F43), contract clauses during termination of contract and dispute resolution (F44), guarantees and bonds (F45).

Before bidding the construction project, the contractors and clients have to look into the contract documents and clauses and external issues such as rules, regulations and formalities of the government. The project stakeholder's may often misinterpret and misunderstand the bidding clauses and documents, thus erupting conflicts among them. These aspects must be given due importance even before signing of the contract so as to avoid future conflicts which may affect budget in a project. 


\section{Group 4: Construction and operational risk}

Group 4 contributes $10.26 \%$ of total variance of the linear component and has eight factors such as Availability of power supply at site, transport, approach to site, proximity of site, airport, port, telecom, water, terrain (F15), difficulty in obtaining permits, project approvals from local bodies, electricity board, water, etc. (F16), climate and weather conditions which may affect the progress of work/working hours (F17), project quality plan satisfies the requirement of quality control and quality assurance (F27), price escalation of materials like steel, cement, metals (F30), support or protest from the local bodies for the project (F39), working capital requirement, Interest cost (F40), fluctuation in the currency rate (F42).

Unplanned projects never reach success. Project plan is to be created with contingencies, evaluated and to be tracked in each phase. Due importance is to be given for the execution of project plan. Project planning professionals should take care of these above mentioned factors (viz., F15, F16, F17, F27, F30, F39, F40, F42) related to construction and operational risk in the project scheduling (phase) to avoid time overrun which in turn may affect the project cost.

\section{Group 5: Resource productivity risk}

Group 5 contributes $8.028 \%$ of total variance of the linear component and consists of five factors such as construction methods/quality/safety requirements for workers (F19), availability of skilled and competent labours (F22), availability of materials, sources and quality and storage facilities (F24), cost of rework and bad workmanship (F28), contract management issues (timely submission, documentation) (F32).

Established and proven modern techniques and tools are to be used for resource scheduling and controlling. Resource need to be arranged as per the availability, terrain, demography, budget, objective etc. Utmost care is to be taken to derive maximum productivity from resource, either material or manpower. Safety is as vital as execution of the project. Inventory scheduling is to be calculated and resources are to be stocked/made available based on requirement. Rework due to bad workmanship can be rectified by adopting competent and skilled labours. Thus by adopting the above measures resource related issues can be minimised and hence productivity can be improved.

\section{Group 6: Knowledge sharing risk}

Group 6 accounts for $7.59 \%$ of total variance of the linear component and consists of five factors such as client specifications (F6), project schedule (F7), design complexity (F8), site clearance/availability of land (F14) and commissioning requirement/handing over (F31).

Project information and knowledge are to be shared with the project stake holders throughout the life cycle of the project. The terms and conditions and specifications of the client have to be shared among the stake holders. Availability of land, legal complications involved in acquisition/obtention of clearance are to be discussed during initial stage much before the execution of work. Knowledge management approach has to be implemented between top, middle and lower management. Tacit knowledge and explicit knowledge have to be shared among the team members. 
Offer and acceptance issues between the client and the contractor should be discussed during the pre-bidding stage of the project. Construction agreement should include all these issues and there should be a proper communication among the stakeholders which may avoid unnecessary delays in starting and handing over the project.

\section{Group 7: Site supervision risk}

Group 7 contributes $4.355 \%$ of total variance of the linear component and consists of two factors such as location of site (F12), availability and productivity of plant and machinery (owned/hire), working and maintenance conditions and mobilisation (F26).

Access to site location, availability of local/skilled workers, plant and machineries are to be ensured for smooth execution of the project. Wherever remote location is selected, alternate arrangements are to be kept ready. Simple maintenance free multipurpose equipments are to be preferred at project location with remote/limited access. Special equipment may be avoided in such areas. Proper site supervision would enhance the completion of the project within stipulated budget.

\section{Group 8: Financial viability risk}

Group 8 accounts for $3.145 \%$ of total variance of the linear component and mainly deals with the Cash flow in the project (F41). In a construction project, cash flow factor is very important. In order to mitigate financial viability risk, proper attention needs to be given for capital requirement, means of funding, and preparation of budget with contingencies. The issues may be avoided by arranging reliable source of funds and choosing trustworthy contractor/client. This part of risk is to be handled by financial consultants in co-ordination with project engineers.

\section{Group 9: Lean construction risk}

Group 9 contributes $2.898 \%$ of total variance of the linear component. This group comprises of only one factor i.e., material wastages exceeding the tolerances limit (F25). In order to maintain sustainability and more stable work flow at site, lean construction approach can be adopted. Reducing wastages in the construction industry could yield great cost savings. Material wastages arise out of last minute client changes, errors by tradesman purchased products that do not comply with specification and lack of onsite material control. Project managers have to find better alternatives to recycle the wastage materials on site and to find measures to prevent the occurrence of waste, so that the cost of wasted materials can be reduced considerably thereby reducing project cost. 
Table 3. Factor Analysis: Extraction of Groups

\begin{tabular}{|c|c|c|c|c|c|}
\hline $\begin{array}{l}\text { Item } \\
\text { No. }\end{array}$ & Description of the Factors & $\begin{array}{l}\text { Factor } \\
\text { Loadings }\end{array}$ & $\begin{array}{c}\% \text { of } \\
\text { Variance }\end{array}$ & $\begin{array}{c}\text { Cumulative } \\
\%\end{array}$ & $\begin{array}{l}\text { Cronbach } \\
\text { Alpha Value }\end{array}$ \\
\hline \multicolumn{6}{|c|}{ Rotated Component Matrix } \\
\hline & \multicolumn{5}{|c|}{ Group 1: Project scope and evaluation risk } \\
\hline $\mathrm{F} 1$ & Funding arrangements & 0.709 & 12.940 & 12.940 & 0.912 \\
\hline F2 & $\begin{array}{l}\text { Standard and practices of } \\
\text { client }\end{array}$ & 0.775 & & & \\
\hline F3 & $\begin{array}{l}\text { Contract type and conditions } \\
\text { and procedures }\end{array}$ & 0.667 & & & \\
\hline $\mathrm{F} 4$ & Unclarity of objective & 0.572 & & & \\
\hline F5 & Client credibility & 0.744 & & & \\
\hline F11 & $\begin{array}{l}\text { Availability of professional } \\
\text { competency and experience }\end{array}$ & 0.835 & & & \\
\hline F29 & $\begin{array}{l}\text { Subcontractor and vendors } \\
\text { capability to perform and } \\
\text { delivery methods }\end{array}$ & 0.727 & & & \\
\hline \multirow[t]{2}{*}{ F46 } & $\begin{array}{l}\text { Vagueness of contract laws } \\
\text { and conditions }\end{array}$ & 0.637 & & & \\
\hline & \multicolumn{5}{|l|}{ Group 2: Work environment risk } \\
\hline F9 & Engineering inputs from clients & 0.791 & 11.656 & 24.596 & 0.9 \\
\hline F10 & $\begin{array}{l}\text { Timely preparation and } \\
\text { delivery of drawing by } \\
\text { design team }\end{array}$ & 0.639 & & & \\
\hline $\mathrm{F} 13$ & Soil conditions & 0.749 & & & \\
\hline F18 & $\begin{array}{l}\text { Any extremist activities } \\
\text { (naxalaties, moist, mafia } \\
\text { groups, local dadas) }\end{array}$ & 0.736 & & & \\
\hline F20 & Frontline supervisory force & 0.875 & & & \\
\hline F21 & Support for import formalities & 0.687 & & & \\
\hline F23 & $\begin{array}{l}\text { Productivity of local } \\
\text { employees and ration } \\
\text { of local employment }\end{array}$ & 0.571 & & & \\
\hline \multirow[t]{2}{*}{ F33 } & Ambiguity of work legislations & 0.642 & & & \\
\hline & \multicolumn{5}{|c|}{ Group 3: Documentation and legal framework risk } \\
\hline F34 & $\begin{array}{l}\text { Rules and regulations of } \\
\text { the government }\end{array}$ & 0.717 & 11.089 & 35.685 & 0.89 \\
\hline F35 & $\begin{array}{l}\text { Visa formalities and } \\
\text { immigration rules }\end{array}$ & 0.765 & & & \\
\hline F36 & $\begin{array}{l}\text { Taxation laws by the } \\
\text { government }\end{array}$ & 0.527 & & & \\
\hline
\end{tabular}


Table 3. (continued)

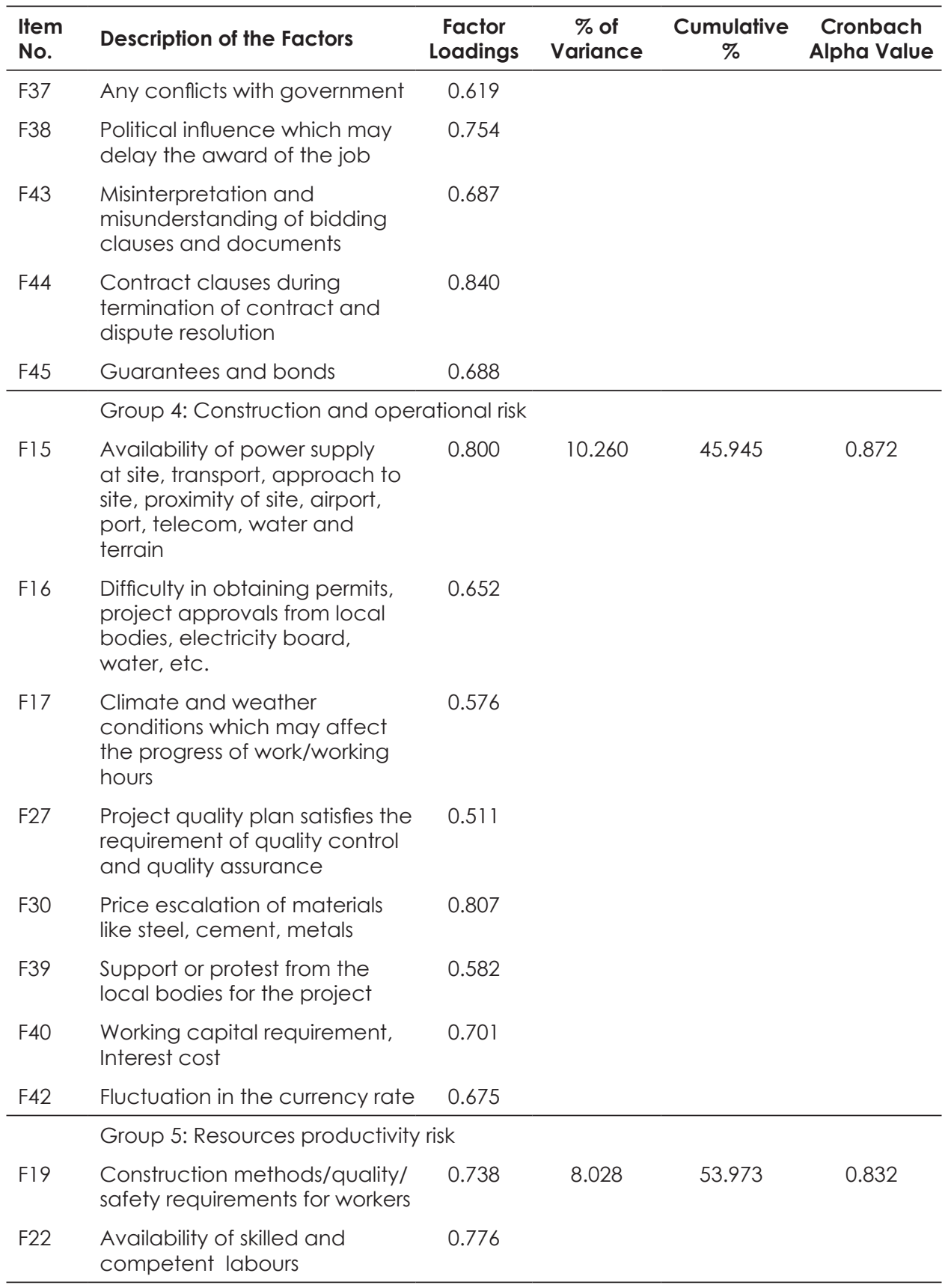


Table 3. (continued)

\begin{tabular}{|c|c|c|c|c|c|}
\hline $\begin{array}{l}\text { Item } \\
\text { No. }\end{array}$ & Description of the Factors & $\begin{array}{l}\text { Factor } \\
\text { Loadings }\end{array}$ & $\begin{array}{c}\% \text { of } \\
\text { Variance }\end{array}$ & $\begin{array}{c}\text { Cumulative } \\
\%\end{array}$ & $\begin{array}{l}\text { Cronbach } \\
\text { Alpha Value }\end{array}$ \\
\hline F24 & $\begin{array}{l}\text { Availability of materials, } \\
\text { sources and quality and } \\
\text { storage facilities }\end{array}$ & 0.783 & & & \\
\hline F28 & $\begin{array}{l}\text { Cost of rework and bad } \\
\text { workmanship }\end{array}$ & 0.764 & & & \\
\hline \multirow[t]{2}{*}{ F32 } & $\begin{array}{l}\text { Contract management } \\
\text { issues (timely submission, } \\
\text { documentation) }\end{array}$ & 0.549 & & & \\
\hline & Group 6: Knowledge sharing risk & & & & \\
\hline F6 & Client specifications & 0.594 & 7.592 & 61.565 & 0.852 \\
\hline F7 & Project schedule & 0.874 & & & \\
\hline F8 & Design complexity & 0.701 & & & \\
\hline $\mathrm{F} 14$ & $\begin{array}{l}\text { Site clearance/availability of } \\
\text { land }\end{array}$ & 0.891 & & & \\
\hline \multirow[t]{2}{*}{ F31 } & $\begin{array}{l}\text { Commissioning requirement/ } \\
\text { handing over }\end{array}$ & 0.527 & & & \\
\hline & Group 7: Site supervision risk & & & & \\
\hline $\mathrm{F} 12$ & Location of site & 0.862 & 4.355 & 65.920 & 0.701 \\
\hline \multirow[t]{2}{*}{ F26 } & $\begin{array}{l}\text { Availability and productivity } \\
\text { of plant and machinery } \\
\text { (owned/hire), working and } \\
\text { maintenance conditions, } \\
\text { mobilisation }\end{array}$ & 0.768 & & & \\
\hline & Group 8: Financial viability risk & & & & \\
\hline \multirow[t]{2}{*}{$\mathrm{F} 41$} & Cash flow in the project & 0.768 & 3.142 & 69.062 & - \\
\hline & Group 9: Lean construction risk & & & & \\
\hline F25 & $\begin{array}{l}\text { Material wastages exceeding } \\
\text { the tolerances limit }\end{array}$ & 0.688 & 2.898 & 71.960 & - \\
\hline
\end{tabular}

\section{Model Development}

Critical risk factors contributing for cost deviation were further analysed by binary logistic regression for developing a predictive model. While factor analysis depicted the existence of clusters of large correlation coefficients with measurable underlying groups, such groups do not possess predictive power of any order on the measured phenomena (Doloi et al., 2012). Hence, binary logistic regression analysis was used for creating a predictive model combining a set of independent variables for estimating the probability of cost deviation. 


\section{Logistic Regression}

Logistic regression is one of the powerful analytical techniques for use, when the outcome variable is dichotomous. Logistic regression model was framed to measure the probability of cost deviation and is expressed as:

$$
\operatorname{Logit}(P)=\beta_{0}+\beta_{1} x_{1}+\beta_{2} x_{2}+\beta_{3} x_{3}+\beta_{4} x_{4}+\beta_{5} x_{5}+\beta_{6} x_{6}
$$

Binary logistic regression is a method by which one could classify the subjects based on a set of predictor values. The dependent variable here is the cost deviation which is a category data. The respondents were asked to provide details about cost deviation in the particular project. The mean score of the each group was calculated for the below mentioned underlying groups like Group 1: Project scope and evaluation risk, Group 2: Work environment risk, Group 3: Documentation and legal framework risk, Group 4: Construction and operational risk, Group 5: Resources procurement risk, Group 6: Knowledge sharing risk, Group 7: Site supervision risk, Group 8: Financial viability risk, Group 9: Lean construction risk and they were related to the dependent variable to find the probability of cost deviation. The probability of cost deviation lies between 0 and 1. For the analysis, the reference category (cost deviation) considered as "less" or "more". The logistic regression analysis was carried out with SPSS 20.0 statistical tool and the results are summarised below.

\section{Estimation of Goodness of Fit}

The model fitting information is presented in Table 4. Final model was arrived through an iterative process that maximises the log likelihood of the outcomes seen in the outcome variable. Since the significance value from this analysis was less than 0.05 , it was inferred that the variable was significant.

Table 4. Model Fitting Information

\begin{tabular}{lcccc}
\hline Model & -2 Log Likelihood & $\begin{array}{c}\text { Chi-Square } \\
\text { Value }\end{array}$ & $\begin{array}{c}\text { Degrees of Freedom } \\
\text { (df) }\end{array}$ & $\begin{array}{c}\text { Significance } \\
\text { (Sig.) }\end{array}$ \\
\hline Final & 182.793 & 126.31 & 9 & 0.00 \\
\hline
\end{tabular}

The pseudo $R$ square statistic can be interpreted as the variation in the dependent variable that was explained by the model. Since this model involved multiple independent variables, the value of Cox and Snell $R$ square and Nagelkerke $R$ square were 0.432 and 0.577 respectively. The results of the score test indicated that the groups 1, 2, 3, 6, 8 and 9 were having the significant values less than 0.05 . This implies that these groups have more contribution in the cost deviation model.

\section{Cost deviation model}

Table 5 gives the effect of risk groups on "Cost deviation". The Wald statistic was obtained by squaring the ratio of the $B$ coefficient to the standard error. 
In this study, the risk groups having less than 0.05 significance and contributing more to the cost deviation were project scope and evaluation risk, work environment risk, construction and operational risk, resources productivity risk, knowledge sharing risk, lean construction risk.

$\operatorname{Exp}(B)$ was the odds ratio for each risk group. In Table 5, the project scope and evaluation risk (G1) having odds ratio of 2.973 implies that the number of projects having "more" cost deviation is 2.973 times higher than that of the projects having "less" cost deviation, assuming no change in the values of the other groups. This indicates that the risk group has a significant relationship with dependent variable (cost deviation). Similarly, the odds ratio can be interpreted for other groups having significance values, less than 0.05 .

Table 5. Logistic Regression Results

\begin{tabular}{|c|c|c|c|c|c|c|c|}
\hline \multicolumn{2}{|c|}{ Cost Deviation Factors } & \multirow{2}{*}{$\begin{array}{c}\text { B } \\
1.090\end{array}$} & \multirow{2}{*}{$\begin{array}{c}\begin{array}{c}\text { Std. } \\
\text { Error }\end{array} \\
0.320\end{array}$} & \multirow{2}{*}{$\begin{array}{l}\text { Wald } \\
11.614\end{array}$} & \multirow{2}{*}{$\frac{\text { df }}{1}$} & \multirow{2}{*}{$\begin{array}{c}\text { Sig. } \\
0.001\end{array}$} & \multirow{2}{*}{$\begin{array}{r}\operatorname{Exp}(B) \\
2.973\end{array}$} \\
\hline $\begin{array}{l}\text { Step } \\
\text { method }\end{array}$ & $\begin{array}{l}\text { Project scope and evaluation } \\
\text { risk (G1) }\end{array}$ & & & & & & \\
\hline & Work environment risk (G2) & 1.132 & 0.316 & 12.828 & 1 & 0.000 & 3.103 \\
\hline & $\begin{array}{l}\text { Documentation and legal } \\
\text { framework risk (G3) }\end{array}$ & -0.191 & 0.342 & 0.311 & 1 & 0.577 & 0.826 \\
\hline & $\begin{array}{l}\text { Construction and operational } \\
\text { risk (G4) }\end{array}$ & -1.167 & 0.351 & 11.076 & 1 & 0.001 & 0.311 \\
\hline & Resources productivity risk (G5) & -0.749 & 0.260 & 8.300 & 1 & 0.004 & 0.473 \\
\hline & Knowledge sharing risk (G6) & 0.748 & 0.273 & 7.490 & 1 & 0.006 & 2.113 \\
\hline & Site supervision risk (G7) & -0.217 & 0.231 & 0.881 & 1 & 0.348 & 0.805 \\
\hline & Financial viability risk (G8) & -0.169 & 0.197 & 0.738 & 1 & 0.390 & 0.844 \\
\hline & Lean construction risk (G9) & 1.231 & 0.273 & 20.328 & 1 & 0.000 & 3.426 \\
\hline & Constant & -3.929 & 1.034 & 14.449 & 1 & 0.000 & 0.020 \\
\hline
\end{tabular}

The risk groups having significant value less than 0.05 (Table 5) were considered for developing the utility equation for estimating the probability of cost deviation as below.

$$
\begin{aligned}
\log \left(P_{[\text {Cost deviation }]}\right)= & -3.929+1.090 * \mathrm{G} 1+1.132 * \mathrm{G} 2-1.167 * \mathrm{G} 4 \\
& -0.749 * \mathrm{G} 5+0.748 * \mathrm{G} 6+1.231 * \mathrm{G} 9
\end{aligned}
$$

\section{Hosmer-Lemeshow test results}

The Hosmer-Lemeshow test measures overall fit of the model and it is indicated in Table 6. Since the $p$-value $>0.05$ with chi-square value 9.177, the model holds a good fit. 
Table 6. Hosmer-Lemeshow Test Results

\begin{tabular}{cccc}
\hline Step & Chi-Square & df & Sig. \\
\hline 1 & 9.177 & 8 & 0.15 \\
\hline
\end{tabular}

\section{Classification accuracy results}

The classification accuracy is indicated in Table 7. Out of 223 respondents, 113 stated (observed) lesser risk and 110 stated (observed) higher risk. The overall percentage correctness of the model was found to be $84.8 \%$ which implies good model fit.

Table 7. Classification Accuracy Table

\begin{tabular}{lccccc}
\hline \multirow{2}{*}{ Cost Deviation } & & \multicolumn{2}{c}{ Predicted } & \multirow{2}{*}{ Percentage Correctness } \\
\cline { 3 - 5 } & & & Less & More & \\
\hline Observed & Less & 113 & 91 & 22 & 80.5 \\
& More & 110 & 12 & 98 & 89.1 \\
\multirow{2}{*}{ Overall percentage } & 223 & 103 & 120 & 84.8 \\
\hline
\end{tabular}

\section{CONCLUSIONS}

Managing risks in construction projects has been recognised as a very important process in order to achieve project objectives in terms of time, cost, quality, safety and environmental sustainability (Zou, Zhang and Wang, 2007).

This study includes the identification of risk factors and the development of model for estimating the probability of cost deviation in medium sized construction projects. A questionnaire survey comprising of 46 identified risk factors was conducted with field experts. 223 responses were collected from professionals employed at various medium sized projects in South India.

The top five factors among 46 factors were identified by ranking the factors based on the mean value of the respondents. The most important factor was commissioning requirement/handing over with highest mean value of 3.30 .

The results of the reliability analysis indicated that Cronbach alpha value is 0.974 which proves the validity of data. The responses were analysed by two statistical techniques namely factor analysis and binary logistic regression.

The KMO value of 0.741 from the factor analysis implies good model fit. By data reduction technique the 46 factors were classified under nine groups such as project scope and evaluation risk, work environment risk, documentation and legal framework risk, knowledge sharing risk, site supervision risk, financial viability risk and lean construction risk. These nine groups accounted for $71.96 \%$ total variance. These findings were supported by previous researchers who studied on risks in construction project in various developing countries are listed in Table 1. Zou, Zhang and Wang (2007) concluded that the factors like poor funding problem, poor Knowledge and skills of subcontractors will lead to construction risks in china. Jha and Devaya (2010) concluded that the factors like political instability, ambiguous project scope definition and poor project management are the key risks in Indian 
context. A logistic regression model was developed to estimate the probability of cost deviation and to identify the significant association between the cost deviation and the nine underlying groups. The results from the logistic regression indicated that the cost deviation was significantly associated with six of the advocated groups. The significant groups which are (1) project scope and evaluation risk, (2) work environment risk, (3) knowledge sharing risk, (4) lean construction risk, (5) construction and operational risk and (6) resources productivity risk were having odds ratio of $2.973,3.103,2.113,3.426,0.311$ and 0.473 respectively. Higher odds ratio implied higher influence on cost deviation. The goodness of fit of the model was confirmed by -2 log likelihood, pseudo $R$ square, Cox and Snell $R$ square, nagelkeren $R$ square and Hosmer-Lemeshow tests. The percentage correctness of the predictor variable (cost deviation) was found to be $84.8 \%$ from the classification accuracy table in logistic regression, proving good model fit.

Thus the proposed model can be used by the contractors to forecast and to provide some cost contingency at the pre bidding stage of the construction project and hence the project success can be achieved.

This research would be helpful for the practitioners and academicians in construction industry for further research in this area. This study is conducted in southern part of India with the response rate of $44.6 \%$. Similar studies can be conducted covering the all parts of India and in other countries with more response rate. Moreover, this study is carried out targeting the medium sized construction projects and this can be extended for large construction projects.

\section{RECOMMENDATIONS}

The identified risk factors were grouped under nine groups and further the logistic regression analysis showed that six groups have higher influence on cost deviation. Recommendations to mitigate the risk in medium sized construction projects causing cost deviation are given below.

Adopting the lean principles at work site, the material wastages can be minimised within tolerance limit and thereby, lean construction risk can be overcome. By motivating, all the construction professionals and by creating a safe environment for labours, the work environment risk can be eliminated. By enhancing the working culture, the productivity can be improved.

By clearly defining the project scope and by evaluating the project risk at the beginning stage of the construction project by the project parties, the project scope and evaluation risk can be reduced.

Majority of the company's management follow top down approach which was a traditional approach, but bottom up approach may be followed wherein employee's contribution and suggestion shall be heard, the knowledge sharing risk can be avoided.

Optimising the use of materials and by maintaining a cordial good relationship with regulatory/statutory bodies, the resource procurement risk and the construction and operational risk can be eliminated. Construction operational feasibilities like availability of power, water, and transportation are to be ensured and suitable alternatives have to be made to avoid unnecessary delay.

Out of 223 collected data, only 93 projects (41.7\%) have implemented the risk analysis in their projects. From the survey, it was understood that risk management was not followed in most of the companies in India as such, even if followed it 
is not done systematically. Immediate mitigation measures are not in practice if a risk event happens. In pre-bidding process, the detailed project report, original estimate and budget of the project have to be effectively prepared by forecasting the risks involved in the project planning and scheduling of activities are to be made as a continuous process during construction and also to be tracked for any deviation on budget. Since there is no clear understanding of these key risk groups among the contractors, a sincere attempt was made in this research to estimate the probability of cost deviation in medium sized construction projects and suitable recommendations are given to mitigate the risks.

\section{REFERENCES}

Abdelgawad, M. and Fayek, A.R. (2010). Risk mangement in the construction industry using combined fuzzy FMEA and fuzzy AHP. Journal of Construction Engineering and Management, 136(9): 1028-1036. https://doi.org/10.1061/ (ASCE)CO.1943-7862.0000210.

Baghdadi, A. and Kishk, M. (2015). Saudi Arabian aviation construction projects: Identification of risks and their consequences. Procedia Engineering, 123: 3240. https://doi.org/10.1016/j.proeng.2015.10.054.

Baloi, D. and Price, A.D.F. (2003). Modelling global risk factors affecting construction cost performance. International Journal of Project Management, 21 (4): $261-$ 269. https://doi.org/10.1016/S0263-7863(02)00017-0.

Bing, L., Akintoye, A., Edwards, P.J. and Hardcastle, C. (2005). The allocation of risk in PPP/PFI construction projects in the UK. International Journal of Project Management, 23(1): 25-35. https://doi.org/10.1016/j.ijproman.2004.04.006.

Chua, D.K.H. and Li, D. (2000). Key factors in bid reasoning model. Journal of Construction Engineering and Management, 126(5): 349-357. https://doi. org/10.1061/(ASCE)0733-9364(2000) 126:5(349).

Dey, P.K. (2002). Project risk management: A combined analytical hierarchy process and decision tree approach. Cost Engineering, 44(3): 13-26.

Dikmen, I., Birgonul, M.T. and Han, S. (2007). Using fuzzy risk assessment to rate cost overrun risk in international projects. International Journal of Project Management, 25(5): 494-505. https://doi.org/10.1016/j.ijproman.2006.12.002.

Doloi, H., Sawhney, A., lyer, K.C. and Rentala, S. (2012). Analysing factors affecting delays in Indian construction projects. International Journal of Project Management, 30(4): 479-489. https://doi.org/10.1016/j.ijproman.2011.10.004.

Dulaimi, M.F. and Shan, H.G. (2002). The factors influencing bid mark-up decisions of large and medium size contractors in Singapore. Construction Management and Economics, 20(7): 601-610. https://doi.org/10.1080/01446190210159890.

Enshassi, A. and Mosa, J.A. (2008). Risk management in building projects: Owners perspective. The Islamic University Journal (Series of Natural Studies and Engineering), 16(1): 95-123.

Eybpoosh, M., Dikmen, I. and Birgonul, M.T. (2011). Identification of risk paths in international construction projects using structural equation modeling. Journal of Construction Engineering and Management, 137(12): 1164-1175. https://doi.org/10.1061/(ASCE)CO.1943-7862.0000382. 
Goh, C.S., Rahman, H.A. and Samad, Z.A. (2013). Applying risk management workshop for a public construction project: Case study. Journal of Construction Engineering and Management, 139(5): 572-580. https://doi.org/10.1061/ (ASCE)CO.1943-7862.0000599.

Hair, J.F., Black, W.C., Babin, B.J., Anderson, R.E. and Tatham, R.L. (2012). Multivariate Data Analysis. 6th Ed. New Jersey: Pearson.

Hwang, B.-G., Zhao, X. and Toh, L.P. (2014). Risk management in small construction projects in Singapore: Status, barriers and impact. International Journal of Project Management, 321 (1):16-124. https://doi.org/10.1016/j.ijproman.2013. 01.007.

Jha, K.N. and Devaya, M.N. (2010). Modelling the risks faced by Indian construction companies assessing international projects. Construction Management and Economics, 26(4): 337-348. https://doi.org/10.1080/01446190801953281.

Klynveld Peat Marwick Goerdeler (KPMG) (2013). Study on Project Schedule and Cost Overruns: Expedite Infrastructure Projects. New Delhi: Project Management Institute (PMI)-KPMG. Available at: https://www.pmi.org.in/pdfs/white_paper/ PMI_WhitePaper_301120171237_study-on-project-schedule-and-cost.pdf.

Laryea, S. and Hughes, W. (2011). Risk and price in the bidding process of contractors. Journal of Construction Management and Engineering, 137(4): 248-258. https://doi.org/10.1061/(ASCE)CO.1943-7862.0000293.

Mubarak, S. (2010). Construction Project Scheduling and Control. New York: John Wiley and Sons. https://doi.org/10.1002/9780470912171.

Nunnally, J.C. (1978). Psychometric Theory. 2nd Ed. New York: McGraw-Hill.

Ogunsanmi, O.E., Salako, O.A. and Ajayi, O.M. (2011). Risk classification model for design and build projects. Journal of Engineering, Project and Production Management, 1(1): 46-60. https://doi.org/10.32738/JEPPM.201 107.0006.

Park, J., Park, B., Cha, Y. and Hyun, C. (2016). Risk factors assessment considering change degree for mega-projects. Procedia Social and Behavioral Sciences, 218: 50-55. https://doi.org/10.1016/j.sbspro.2016.04.009.

Renuka, S.M., Umarani, C. and Kamal, S. (2014). A review on critical risk factors in the life cycle of construction projects. Journal of Civil Engineering Research, 4(2A): 31-36.

Serpella, A.F., Ferrada, X., Howard, R. and Rubio, L. (2014). Risk management in construction projects: A knowledge-based approach. Procedia Social and Behavioral Sciences, 119: 653-662. https://doi.org/10.1016/j. sbspro.2014.03.073.

Shen, L.Y., Wu, G.W.C. and Ng, C.S.K. (2001). Risk assessment for construction joint ventures in China. Journal of Construction Engineering and Management, 127(1): 76-81. https://doi.org/10.1061/(ASCE)0733-9364(2001) 127:1 (76).

Smith, G.R. and Bohn, C.M. (1999). Small and medium contractor contingency and assumption of risk. Journal of Construction Engineering Management, 125(2): 101-109. https://doi.org/10.1061/(ASCE)0733-9364(1999)125:2(101).

Tamosaitiene, J., Zavadskas, E.K. and Turkis, Z. (2013). Multi-criteria risk assessment of a construction project. Procedia Computer Science, 17: 129-133. https://doi. org/10.1016/j.procs.2013.05.018.

Taroun, A. (2014). Towards a better modeling and assessment of construction risk Insights from a literature review. International Journal of Project Management, 32(1): 101-115. https://doi.org/10.1016/j.ijproman.2013.03.004. 
Thomas, A.V., Kalidindi, S. and Ganesh, L.S. (2006). Modelling and assessment of critical risks in BOT road projects. Construction Management and Economics, 24(4): 407-424. https://doi.org/10.1080/01446190500435275.

Toh, T.-C., Ting, C., Ali, K.-N., Aliagha, G.-U. and Munir, O. (2012). Critical cost factors of building construction projects in Malaysia. Procedia Social and Behavioral Sciences, 57: 360-367. https://doi.org/10.1016/j.sbspro.2012.09.1198.

Torp, O., Belay, A.M., Thodesen, C. and Klakegg, O.J. (2016). Cost development over time at construction planning phase: Empirical evidence from Norwegian construction projects. Procedia Engineering, 145: 1177-1184. https://doi. org/10.1016/j.proeng.2016.04.152.

Wang, J. and Yuan, H. (2011). Factors affecting contractors risk attitudes in construction projects: Case study from China. International Journal of Project Management, 29(2): 209-219. https://doi.org/10.1016/j.ijproman.2010.02.006.

Wang, S.Q., Dulaimi, M.F. and Aguria, M.Y. (2004). Risk management framework for construction projects in developing countries. Construction Management and Economics, 22(3): 237-252. https://doi.org/10.1080/014461903200012468 9.

Zeng, J.M. and Smith, N.J. (2007). Application of a fuzzy based decision making methodology to construction project risk assessment. International Journal of Project Management, 25(6): 589-600. https://doi.org/10.1016/j. ijproman.2007.02.006.

Zinbarg, R., Revelle, W., Yovel, I. and Li, W. (2005). Cronbach's, Revelle's and McDonald's: Their relations with each other and two alternative conceptualizations of reliability. Psychometrika, 70: 123-133. https://doi.org/ 10.1007/s $11336-003-0974-7$.

Zou, P.X.W., Zhang, G. and Wang, J. (2007). Understanding the key risks in construction projects in China. International Journal of Project Management, 25(6): 601614. https://doi.org/10.1016/j.ijproman.2007.03.001. 